UDC: $372.7(477)$

DOI: https://doi.org/10.24195/2414-4665-2017-5-14

\author{
Nataliia Terokhina, \\ PhD (Candidate of Pedagogical Sciences), associate professor, \\ Department of Foreign Languages, \\ Sumy National Agrarian University, \\ 160, H. Kondratieva Str., Sumy, Ukraine
}

\title{
RECOGNITION OF THE RESULTS OF NON-FORMAL ADULT EDUCATION: AMERICAN EXPERIENCE
}

The article deals with the issue of recognition of the results of non-formal adult education in the US. The following forms of recognition are distinguished: certification, validation, identification. Validation means the confirmation by the competent authority of the results of study acquired by a person in formal, non-formal and informal education. Validation of the results of non-formal adult education involves identification, evaluation and recognition of knowledge and skills an adult person acquires during his/her life. Referring to the validation of the results of non-formal adult education in the United States, the following terms are used: RPL (Recognition of prior learning), APL (Accreditation of prior previous learning), PLA (Prior learning assessment) and PLAR (Prior learning assessment recognition). The mechanisms of non-formal adult education validation used in the United States are the credit system ACE and the program CLEP. The basic methods of validation are testing, examination, discussion, interviewing, expert explanations, surveillance, simulations, demonstration of knowledge, training, communicative and social skills, declarative methods, critical reflection, portfolio method. Strategic directions of validation of non-formal adult education prove its important role in the economy and society in general, social integration of people and their professional mobility, implementing the concept of lifelong education, compliance with the basic characteristics of the United States as a country of equal opportunities, democracy, justice and freedom whose experience should be adopted by Ukraine.

Keywords: non-formal education, adult education, validation, credit system, the USA.

\section{Introduction}

Recognition of prior learning, including the results of non-formal education of adults is one of the key areas of educational policy in many countries, determined by the intensive development of non-formal adult education which is caused by the transition of the mankind to the information society and the decreasing of the number of educational institutions providing formal education. Nonformal adult education has great educational potential, flexibly responding to the educational needs of adults, labor market, the society.

In modern Ukrainian pedagogy, American system of education is studied by a number of researchers. The issue of university education humanization in the USA was investigated by R. Belanova, O. Zabolotna, O. Romanovskyi; the experience of organizing pedagogical education was analyzed by V. Zhukovskyi, T. Koshmanova, L. Puhovskyi, M. Leshchenko; integration and globalization processes of lifelong education were investigated by T. Desiatov, V. Kudin, A. Matvienko, O. Ohienko, S. Romanova, A. Sbruieva; the issue of female educationin the United States was studied by N. Kutova, O. Terenko. Non-formal and further education of adults was studied by F. Pohhler (Germany); M. Knowles, E. Lindeman, S. Merriam, D. Mezirov, F. Coombs, S. Brookfield (USA); R. Broket, P. Cross (Canada); P. Jarvis, A. Rogers (England); L. Turos (Poland) and others. Various aspects of adult education and lifelong learning were examined by S. Vershlovskyi, B. Hershunskyi, S. Zmeyev, M. Clarin, L. Lesohina, A. Mitina (Russia). Though despite the great number of works dedicated to the issue of American education, the foreign and national scientific literature review leads to the conclusion that the issue of recognizing the results of non-formal adult education in the United States still remains understudied both in Ukraine and abroad.

The paper aims to investigate American experience concerning recognition of the results of non-formal adult education in order to consider the possibility of adopting their experience in Ukraine.

Research methods

In our research, we used theoretical methods of analysis, synthesis, substantiation, generalization, systematization of theoretical and practical research data.

Discussion

The researchers distinguish several forms of recognizing the results of learning: certification, validation, identification.

Certification is considered as an element of formal education, the official recognition of institutional education with a diploma or a certificate obtained in a particular institution.

Validation means recognition of competences and knowledge that were mastered by a person regardless of location, form and time of acquisition. Validation of learning outcomes is focused on the competencies gained anywhere and at any time, their value and significance. Its main goal is to "make visible the results of the study" [2]. Validation of the results of non-formal education enhances the professional identity of adults, stimulates interest 
and the need for lifelong learning, increases competitiveness at the labor market.

Identification of non-formal education results is considered as a process reflecting the results of adult education without obtaining a certificate or diploma though giving grounds for its formal recognition [16].

Our investigations show that different countries have different interpretations of the term "validation of the results of non-formal adult education". For example, in Norway and Iceland it is regarded as the removal of barriers for formal education. In Austria and in the UK it is used for getting a formal certificate of education. However, most countries follow the definition that was offered by CEDEFOP, in which validation of the results of nonformal adult education is understood as "confirmation by the competent authority that the results of study acquired by a person in formal, non-formal and informal contexts are evaluated according to pre-established criteria and meet the requirements of validation standards. Typically, validation ofthe results of non-formal education leads to certification [14]. Then validation of the results of nonformal adult education involves identification, evaluation and recognition of knowledge and skills that an adult gains during his/her life: education, work and leisure. We emphasize that there is a relationship between the results of validation of non-formal and formal education of adults.

In the United States, the following terms are used to denote the validation of the results of adults' non-formal education: RPL (Recognition of prior learning) - recognition of prior learning acquired in non-formal and informal context, APL (Accreditation of prior learning) - accreditation of the previous learning, PLA (Prior learning assessment) - evaluation of prior learning and PLAR Prior learning assessment recognition) - recognition of assessment of prior learning [8].

The Council of Adult Experiential Learning (CAEL) defines Prior Learning Assessment (PLA) as a method by which individual experience is transformed into the credit of college. Since knowledge and skills can be acquired from various sources (experience, training, spontaneous learning, social activities, courses, etc.) they can be added to academic credit based on the criteria established by an institution that provides recognition of the results of learning using test, Portfolio method or curriculum analysis.

In 1971, Carnegie Commission in its report "Less time, more choices" called non-formal education (noninstitutional) a great value for education of adults and recommended, first, to create conditions for its implementation and expand opportunities of its use in training specialists, in particular, for industry, army; second, to pay attention to the potential of non-formal education for people of retirement age, to attract adults in lifelong learning; third, provide non-formal educational institutions with budget financing. This report and subsequent activities in recognition of non-formal education can be considered as a response to the changes which were taking place in the American society: changes in the requirements to the employees'competence, the effects of World War II, changes in the demographic composition of those who received education, the increase of the number of women who seek to acquire certain skills and become competitive in the labor market, etc. [6].

Since 1974 there have been established Educational Testing Centers: their mission was to evaluate knowledge and skills of adults, which were acquired through participation in non-formal education and determine their compliance with a certain level of education or to enroll them in the form of academic credit for learning in colleges. American Council on Education (ACE) was the first that was involved in such activity, since 1942 ACE helped former military personnel to get education and today ACE provides services for recognition of non-formal education and its transfer into academic credits of colleges.

According to E. Michelson, validation of the results of non-formal adult education allows to use personal and professional experience of an individual in the process of training and for career opportunities [9]. For example, every American student must learn 124 academic credits in order to get a Bachelor's degree. One academic credit corresponds to 15 hours of study. In most colleges maximum hours that can be enrolled through RPL are 30 credits. Moreover, educational establishments according to the results of validation can transfer in academic or special modules of curriculum. According to statistics future social workers, teachers, service workers get mostly PLA credits for further education [15].

In the United States educational system is highly decentralized, so the process of validation of the results of non-formal education is decentralized, too. For example, in Colorado at the legislative level each institution of higher education has to develop and submit a program to provide academic credit for prior learning. In the state of Washington a special commission is organized to determine the educational policy to provide academic credit to acquired knowledge and skills at workplace, in military forces, colleges, non-formal training programs, etc. [10].

Meanwhile, universities and colleges can offer their approaches in implementing educational initiatives of the state concerning validation of non-formal education results. For example, schools in Minnesota developed a strategy of validation, where "every college and university must provide students with the opportunity of previous experience validation, develop appropriate procedures for providing credit (Procedure 3.35.1 Credit for Prior Learning) [3].

In order to achieve and ensure the efficiency and quality of validation of non-formal adult education results most states consider it as a part of the educational policy "Education throughout life". Thus, according to the law on continuous education of Colorado "lifelong education with professional and personal development must provide recognition of prior learning and professional experience for its transfer in credit of academic curriculum of an institution" [8]. 
Such states as Washington, Tennessee, Pennsylvania, Vermont have similar legislative approaches on validation of the results of non-formal adult education, in particular, they adopted a law that requires the establishment of a working group on valuation procedure and recognition of prior learning and experience and its transfer into academic credits.

Researchers emphasize the factors that determine the effectiveness of the results of validation of non-formal adult education. It is important to mention such of them as partnership and consultation; the availability of sufficient funding and human resources; development of clear guidelines for the procedure of validation; development of methods and procedures based on experience; quality assurance, monitoring and evaluation; exchange of experience [12].

The scientific studies review makes it possible to state that when dealing with adult education special attention is paid to previously acquired knowledge, and adults' professional experience is the dominant factor for labor market.

Validation of the results of non-formal adult education in the United States is implemented by means of different methods and procedures, depending on the preferences of a state or an institution. However, one can distinguish a specific algorithm for its implementation which includes the following six steps: consultation aimed at prior assessment; implementation of selfassessment and identification of previously acquired knowledge and skills in non-formal education; development of an individual plan for assessment; identification of the results of non-formal adult education according to the educational standards of a certain educational institution; getting certificates with acquired competencies; proposals for PLA in a particular establishment; analysis of comments and suggestions of those who took PLA and an opportunity to appeal the results [16].

Let us consider some mechanisms of validation of non-formal adult education outcomes which are used in the United States, such as ACE credit and CLEP program.

The CREDIT program works according to ACE Credit system. College Credit Recommendation Service (CREDIT) is a flexible modular system focused on the ultimate outcome and it is opened to all forms and places of training [5]. It is especially important for labor market. Its implementation has given a new impetus for the development of non-formal adult education in the United States due to the development of accounting system of educational credits. Credit system involves certain steps. First, adults' knowledge and skills are estimated using the following methods and criteria: various tests (alternative, multiple cross-selection, selection of right statements with extended response, etc.), interviews, discussion of issues (work in groups), role-plays and simulation games, selfassessment of previous educational activities, etc.

The second step involves finding out the compliance with existing competencies of academic credits in a col- lege, which is the basis of the credit system in American Council of Education (ACE credit system).

CREDIT is a national leader in evaluating the results of non-formal education. The system includes more than 35000 educational programs which are represented by different providers of non-formal education [9].

Program CLEP (College Level Examination Program) provides an opportunity to demonstrate compliance of adults' educational progress to the level of college through passing exams. Nearly 2900 US colleges give an opportunity to pass the CLEP test. Its successful passing reduces time of study in a college and confirms relevant competencies for the labor market.

The analysis of the US practice of validation of the results of non-formal adult education makes it possible to define the basic methods of its implementation. So, with traditional methods of knowledge assessment (testing, examination) the following ones are used: discussion (one can demonstrate his/her knowledge, communication and social skills, etc; "declarative methods", which are based on self-assessment of candidates of their professional and personal competences according to specially designed criteria. An important component of self-assessment is critical reflection. Competencies are usually confirmed by a third party. An interview is conducted when subjective assessment is required. Usually other methods are used: expert explanation, surveillance which helps to develop competencies while doing certain practical tasks; a simulation method allows to simulate the situation close to reality to show candidate's real competences; a portfolio method helps to prepare a portfolio of individual educational achievements [7].

A portfolio method occupies a special place in the validation of the results of non-formal adult education. It is believed that it is an effective means by which more objective characteristics of competencies acquired by an adult in non-formal education are achieved.

According to our sources there are three aspects in the definition of "portfolio": a) portfolio as a form of presentation of the results of those who study (cumulative portfolio type); b) portfolio as a way of reflexive isolation for those who studied the process and the results of educational and professional activity (portfolio of reflective type), c) portfolio as a means of interaction of the educational process participants (portfolio - process).

According to H. Barrett, there are two types of portfolio that are used to validate the results of previous studies: a portfolio that is created to get academic credits and certificates being a visiting card of personal and professional capacity of a candidate; themed portfolio-property contains candidate's works: pictures, poems, projects, etc. [1].

Consequently, a portfolio of those involved in the validation of the results of non-formal adult education can be of the following types: target assessment and selfevaluation of educational achievements; collection of works, which trace human progress in education; the folder that contains some documents, pictures, etc., that 
serve as a proof of acquired knowledge and experience; anthology of works that demonstrate personal involvement in the selection of adults' works and their selfexamination; video recordings of presentations; various reports, thesis, essays with annotations of colleagues or teachers of candidates; results of written tests [11].

The portfolio method is a very complex process and universities offer short courses which teach how to prepare a portfolio. For example, in the University Chapel (State of Minnesota) and Regis University (Colorado) there are short-term courses ( 3 credits, portfolio learning program). They provide the assessment of candidates' educational achievements, increase motivation and selfconfidence; help to develop a career plan, create and fill in a portfolio, etc.

Validation of the results of non-formal adult education is a difficult and important process for an adult, who is a direct participant, and for a college, university or other organization that creates conditions and determines the criteria. Therefore, according to E. Michelson, it is extremely important to adhere to the principles of validation of the results of non-formal education [11].

Our research shows that much attention is paid in Europe and the USA to the principles of validation. It is more reasonable and appropriate to combine them in six parts: validation targets, which can be formative and summative; individual's rights that are targeted on the needs of adults. Hence, validation must be voluntary, transparent and fair, based on social dialogue, ensuring the protection of personal data, having mechanisms to appeal the results; responsibility of institutions and organizations: validation must be based on human confidentiality; trust and reliability are important principles. It is necessary to provide a person with consulting, legal, practical and information services; create favorable conditions for its implementation. The procedure involves transparency (openness, clarity), accessibility (clarity), impartiality (honest experts, reliable results), legitimacy.

\section{Conclusions}

We have developed some recommendations concerning the procedure of validation of non-formal adult education in accordance with definite principles in the North American educational space: validation must be accessible and transparent, fair and impartial, efficient; it is im-

\section{RFFERENCES}

1. Barrett, H., Carney, J. (2005). Conflicting Paradigms and Competing Purposes in Portfolio Development. Educational Assessment. (Vol. 3) [in English].

2. Bjørnåvold, J. (2000). Making learning visible. Identification, assessment, and recognition of non-formal learning in Europe. Thessaloniki:Cedefop [in English].

3. Center for Continuing Education in Mississippi State University. Retrieved from : http://www.ed2go.com/msstate [in English].

4. Day, M. (2013). Assessment of prior learning: a practitioner's guide. Malcolm Day [2 ${ }^{\text {nd }}$ ed.] London: Cengage LearningVocational [in English]. portant to provide full information on criteria and evaluation methods, it is necessary to conduct counseling and training of candidates for validation; to offer alternative ways of passing validation; credits and certificates obtained in the process of validation must be relevant and equivalent to those received after graduation from establishments of formal education; validation has voluntary basis and provides an opportunity to appeal in case of no consensus of a candidate with the validation results [4].

Therefore, the improvement of the procedure of validating the results of non-formal adult education is one of the key areas of non-formal adult education development in the United States. It is necessary to emphasize the dynamic changes and new approaches to its implementation, based on the desire to meet the educational needs of adults and to increase access to education. Validation of the results of non-formal adult education in the US is performed in the following aspects: validation of the results of education obtained in the process of formal, non-formal and informal education; validation of knowledge and qualifications acquired in the workplace; validation of skills and knowledge acquired during participation in volunteer organizations, social movements, at work. Special attention is paid to validation of adults who want to integrate in the society and labor market, for unemployed people, migrants, people with low level of education and others. These strategic directions of validation determine its important role in the economy and society in general, social integration of people and their professional mobility, implementing the concept of lifelong education, compliance with the basic characteristics of the US as a country of equal opportunities, democracy, justice and freedom. All these principles are very important in terms of adopting the experience of the USA by our country.

The study does not cover all aspects of the issue. The following research topics are interesting and relevant for further studying in this direction: the definition of the peculiarities of organization of training for various categories of population, in particular, migrants, women, the unemployed, people of the "third age" and others in educational institutions of non-formal adult education; generalization of innovative foreign experience in validation of the results of non-formal and informal education, etc.

5. Dyson, C., Keating, Jack (2005). Recognition of prior learning: policy and practice for skills learned at work (Australia, Canada, New Zealand, South Africa, United States). Geneva: International Labour Office [in English].

6. Evans, N. (2000). AP(E)L: Why? Where? How? Setting the international scene. In Evans, N. (Ed). Experiential learning around the world. Employability and the global economy. Philadelphia, PA: Jessica Kingsley Publishers [in English].

7. Leiste, S., Jensen, K. (2011). Creating a Positive Prior Learning Assessment (PLA) Experience: A Step-by- 
Step Look at University PLA. The International Review of Research in Open and Distributed Learning, 1. (Vol. 12). [in English].

8. Learning in Informal and Formal Environments (LIFE) Center. Retrieved from: http://life-slc.org [in English].

9. Mann, C. (1997). Prior learning assessment: US experience facilitating lifelong learning. In K. Barker. Sustainability and efficiency of prior learning assessment in British Columbia's public post-secondary education system: Background paper. Vancouver: British Columbia Ministry of Advanced Education [in English].

10. Lytovchenko, I. (2016) Corporate university as a form of employee training and development in American companies. Advanced education, 5, 35-41 DOI: 10.20535/2410-8286.62280 [in English].

11. Michelson, E. (2004). Portfolio development and the assessment of prior learning: Perspectives, models and practices. $2^{\text {nd }}$ ed. Sterling, VA: Stylus Publishing [in English].

\section{ЛІТЕРАТУРА}

1. Barrett H. Conflicting Paradigms and Competing Purposes in Portfolio Development / H. Barrett, J. Carney // Educational Assessment. - 2005. - Vol. 3. P. 122- 135 .

2. Bjørnåvold J. Making learning visible. Identification, assessment, and recognition of non-formal learning in Europe / J. Bjørnåvold. - Thessaloniki :Cedefop, 2000. - 142 p.

3. Center for Continuing Education in Mississippi State University [Електронний ресурс] - Режим доступу : http://www.ed2go.com/msstate

4. Day M. AssessmentofPriorLearning: A Practitioner'sGuide // MalcolmDay [2 d ed.]- London : CengageLearningVocational, 2013. - 128 p.

5. Dyson C. Recognition of prior learning: Policy and practice for skills learned at work (Australia, Canada, New Zealand, South Africa, United States) / Chloe Dyson, Jack Keating. - Geneva: InternationalLabour Office, 2005. - 72 p.

6. Evans N. AP(E)L: Why? Where? How? Setting the international scene. In Evans, N. (Ed) Experiential learning around the world. Employability and the global economy /N. Evans - Philadelphia, PA: Jessica KingsleyPublishers, 2000 - P. 15-29.

7. Leiste S. Creating a PositivePrior Learning Assessment (PLA) Experience: A Step-by-Step Look at University PLA / Sara M. Leiste and Kathryn Jensen // The International Review of Research in Open and Distributed Learning. - 2011. -Vol. 12. - №1. - P. 61-79.

8. Learning in Informal and Formal Environments (LIFE) Center [Електронний ресурс]. - Режим доступу : http://life-slc.org

9. Mann C. Prior learning assessment: US experiencefacilitating lifelong learning. In K. Barker. Sustainability and efficiency of prior learning assessment in
12. Ogienko, O. (2016) Facilitation in the context of pedagogical activities. Advanced education, 5, 8589. DOI: 10.20535/2410-8286.70621 [in English].

13. Ryu, M. (2013). Credit for prior learning from the student, campus, and industryperspectives. Washington, DC: American Council on Education. Retrieved from: http://www.acenet.edu/news-room/Documents/ Credit-for-Prior-Learning-Issue-Brief.pdf [in English].

14. Tissot, P. (2008). Terminology of education and training policy. A multilingual glossary. Luxembourg: Cedefop. Office for Official Publications of the European Communities [in English].

15. Wihak, C. (2011). Prior Learning Assessment and Recognition: Emergence of a Canadian Community of Scholars. International Review of Research in Open and Distance Learning, 1, 116-122, (Vol. 12) [in English].

16. Werquin, P. (2010). Recognition of non-formal and informal learning: country practices. $O E C D$ [in English].

BritishColumbia's public post-secondary education system: Background paper. - Vancouver: BritishColumbia Ministry of Advanced Education, 1997. - 114 p.

10. Lytovchenko I. Corporate university as a form of employee training and development in American companies / Iryna Lytovchenko // Advanced education. - 2016. - Issue 5. - P. 35-41 DOI: 10.20535/24108286.62280 [in English].

11. Michelson E. Portfolio development and the assessment of prior learning: Perspectives, models and practices / Elana Michelson \&Alan Mandell [2 ${ }^{\text {nd }}$ ed.]. Sterling, VA: Stylus Publishing, 2004. - 304 p.

12. Ogienko O. Facilitation in the context of pedagogical activities / Olena Ogienko // Advanced education. - 2016. - Issue 5. - P. 85-89 DOI: 10.20535/24108286.70621 [in English].

13. Ryu M. Credit for prior learning from the student, campus, and industryperspectives / M. Ryu. Washington, DC: American Council on Education [Електронний ресурс]. - Режим доступу: http://www.acenet.edu/news-room/Documents/ Creditfor-Prior-Learning-Issue-Brief.pdf

14. Tissot P. Terminology of education and training policy. A multilingual glossary / ed. Philippe. - Luxembourg: Cedefop. Office for Official Publications of the European Communities, 2008 [in English].

15. Wihak C. Prior Learning Assessment and Recognition: Emergence of a Canadian Community of Scholars / C. Wihak // International Review of Research in Open and Distance Learning. - 2011. - Vol. 12. - № 1. - P. 116-122.

16. Werquin P. Recognition of non-formal and informal learning: country practices / Patric Werquin. OECD, 2010. - 68 p. 
Наталія Олексіївна Терьохіна, кандидат педагогічних наук, дочент кафедри іноземних мов,

Сумський національний аграрний університет, вул. Г. Когдратьєва, 160, м. Суми, Украӥна

\section{ВИЗНАННЯ РЕЗУЛЬТАТІВ НЕФОРМАЛЬНОӦ ОСВІТИ ДОРОСЛИХ: АМЕРИКАНСЬКИЙ ДОСВІД}

Неформальна освіта дорослих має великий освітній потенціал, вона гнучко реагує на освітні потреби дорослої людини, ринку праці, суспільства. Визнання результатів неформальної освіти дорослих є однією 3 ключових тем освітньої політики багатьох країн світу. Метою статті було вивчення і узагальнення американського досвіду щодо визнання результатів неформальної освіти дорослих. Формами визнання результатів неформального навчання $\epsilon$ сертифікація, валідація, ідентифікація. Валідація результатів неформальної освіти дорослих означає підтвердження компетентним органом того, що результати навчання, які були набуті людиною у формальному, неформальному та інформальному контекстах, оцінені згідно з попередньо встановленими критеріями та відповідають вимогам стандарту валідації. Визначено механізми валідації неформальної освіти дорослих, які використовуються в Сполучених Штатах: кредитна система ACE і програма CLEP. Аналіз американської практики валідації результатів неформальної освіти дорослих дозволив визначити основні методи ії здійснення: тестування, екзамен, дискусія, критична рефлексія, співбесіда, спостереження, моделювання ситуації, метод портфоліо. Валідація результатів неформальної освіти дорослих у США здійснюється у таких аспектах: валідація результатів навчання, які отримані в процесі формального, неформального й інформального навчання; валідація знань і кваліфікацій, що набуті на робочому місці; валідація навичок і знань, що набуті у процесі участі у волонтерських, робочих та інших організаціях і суспільних рухах, валідація результатів неформальної освіти безробітних, мігрантів, людей з низьким рівням освіти та ін. Ці стратегічні напрями валідації неформальної освіти дорослих свідчать про ії важливу роль для розвитку економіки і суспільства, соціальної інтеграції людини і її професійної мобільності, реалізації концепції освіти впродовж життя.

Ключові слова: неформальна освіта, освіта дорослих, валідація, кредитна система, США.

Submitted on April, 17, 2017

Reviewed by Doctor of Pedagogy, prof. O. Ohienko

УДК: 376-054.62:37.011.33:378.4(477)

DOI: https://doi.org/10.24195/2414-4665-2017-5-15

Ху Жунсі,

кандидат педагогічних наук, доцент кафедри східних мов та перекладу, Київький університет імені Бориса Грінченка, вул. Тимошенка, 13-Б, м. Київ, Україна

\section{РЕАЛІЗАЦІЯ ПРОГРАМИ АДАПТАЦІЇ ІНОЗЕМНИХ СТУДЕНТІВ ДО ОСВІТНЬОГО СЕРЕДОВИЩА УНІВЕРСИТЕТІВ УКРАЇНИ}

У статті висвітлено зміст та результати експериментального впровадження програми адаптації іноземних студентів до освітнього середовища вищих навчальних закладів України. Визначено сутність адаптації іноземних студентів до освітнього середовища університетів України. Представлено структурнофункиіональну модель процесу адаптації іноземних студентів до освітнього середовища університетів Украӥни. Охарактеризовано основні педагогічні умови процесу адаптації іноземних студентів до освітнього середовища вищих навчальних закладів Украӥни. Презентовано зміст програми адаптації іноземних студентів до освітнього середовища університетів Украйни. Обгрунтовано результати впровадження програми адаптаиії іноземних студентів до освітнього середовища вищих навчальних закладів України.

Ключові слова: адаптація; адаптація іноземних студентів; освітнє середовище; педагогічні умови; програма адаптації; структурно-функціональна модель.

\section{Постановка проблеми}

Сучасний стан розвитку освіти в Україні характеризується інтенсивним зростанням рівня інтернаціоналізації, що обумовлює збільшення контингенту здобувачів вищої освіти 3 різних країн світу. Проте, процес оволодіння іноземними студентами фаховими компетентностями в українських вищих навчальних закладах ускладнюється суттєвими відмінностями освітніх систем, цінностей, традицій, правил поведінки, соціокультурних осередків. Означене актуалізує 